\title{
Familial Replicating Arachnoidal Cysts: Case Series and Review of Literature
}

\author{
Rosario Maugeri' ${ }^{1}$ David Greg Anderson², Francesca Graziano', Rosa Maria Gerardi ${ }^{1}$, Massimiliano Visocchi ${ }^{3}$ and Domenico Gerardo \\ lacopino $^{1^{*}}$
}

${ }^{1}$ Department of Experimental Biomedicine and Clinical Neurosciences, School of Medicine, Neurosurgical Clinic, University of Palermo, Via del Vespro 129, 90100, Palermo, Italy

${ }^{2}$ Division of Spinal Surgery, Department of Orthopaedic Surgery, The Rothman Institute, Thomas Jefferson University, 925 Chestnut St, 5th floor, Philadelphia, PA, 19107, USA

${ }^{3}$ Institute of Neurosurgery, Policlinico Gemelli, Catholic University School of Medicine, Largo A. Gemelli 8, 00168, Rome, Italy

\begin{abstract}
Background: Arachnoid cysts are intra-arachnoid fluid collections covered by a thin membrane that may develop throughout the cerebrospinal axis. Although the precise causative mechanism is unknown, arachnoid cyst (AC) are now generally accepted to be developmental anomalies of arachnoid. These lesions have commonly been described in the literature; however the presence of familial arachnoid cysts is quite rare. Most genetically related AC have been documented in patients with a known genetic syndrome. The current case report describes a family with four members affected by an arachnoid cyst in the same region.
\end{abstract}

Methods: In addition to reviewing the current case, a literature search was conducted using National Library of Medicine and National Institutes of Health databases to identify articles pertaining to familial Arachnoid cysts. Overall, 32 published articles fit the established review criteria

Results: We describe a family whose members (father and three siblings) present an arachnoid cyst in the same region (the left middle cranial fossa). The general physical findings in the four members were normal and no clinical suggestion of a genetic syndrome. None of the members had an increased head size or abnormal cutaneous findings. Histories of prenatal and perinatal periods were unremarkable. All were born normally at term and none had any history of intrauterine exposure to infection, drugs, teratogens or trauma. Karyotyping failed to reveal abnormalities.

Conclusion: This report extends previous observations that AC can be familial and supports the hypothesis that some cases have a genetic aetiology. The lack of chromosomal or genetic studies in these patients supports the need for additional research into the mechanism of AC formation.

Keywords: Familial; Arachnoid cyst; Review abbreviations

\section{Introduction}

Arachnoid cyst (AC) is a relatively rare central nervous system malformation representing about $1 \%$ of all intracranial masses. In a recent study it was found that the incidence of $\mathrm{AC}$ in the population is $1.4 \%$. Men had a higher prevalence than women. The most common locations are middle fossa (34\%), retro cerebellar (33\%), and convexity (14\%). Middle fossa cysts are predominantly left-sided (70\%). Only $5 \%$ may be symptomatic approximately $70 \%$ of these are considered for surgical treatment. Sellar and suprasellar cysts are more likely symptomatic while middle fossa cysts are less likely to be considered symptomatic [1]. Primary arachnoid cysts are commonly considered to be developmental anomalies of mesodermal origin. These benign lesions involve a separation within the arachnoid membrane that becomes filled with cerebrospinal fluid producing an intrameningeal mass that can compress the surrounding neural tissue. Arachnoid cysts may occur secondary to hemorrhage, trauma, infection or tumours of the central nervous system $[2,3]$.

We report an observational study of four members of the same family who presented AC in the same encephalic region. Few familial cases of AC have been described in the literature. However, some prior reports have identified cases of $\mathrm{AC}$ in association with a specific genetic or chromosomal syndromic pattern. The occurrence of familial arachnoid cyst formation suggests the possibility of a genetic basis for AC formation in some cases [4-6]. Aim of our study was to study all four members of the same family and investigate the scientific literature in order to understand if the presence of replicating of similar AC could be due by a mendelian inheritance.

\section{Material and Methods}

\section{Clinical case}

We describe a case of arachnoid cysts in several members of the same family (father and three siblings) in the same region of the brain (the left middle cranial fossa). The family was identified in inner region of Western Sicily after the incidental finding of an arachnoid cyst in two sisters of the same family. Sister 1 underwent an MR to investigate on seizure activity. Sister 2 had already received a brain MR for evaluation of persistent headaches. Both girls revealed a similar arachnoid cyst in the region of the middle cranial fossa. A head CT scan of the girls' father was also available within the hospital files. The study had been performed as part of the work up for minor head trauma; CT scan revealed a similar arachnoid cyst in the same location of the cranium. We then studied all other members of the family (the girl's mother and her son) by MR (Figure 1).

Although the neuroimaging of the mother was unremarkable, MR

*Corresponding author: Domenico G. lacopino, Department of Experimental Biomedicine and clinical neurosciences University hospital of Palermo, Italy, Tel: +39.091.6554299; Fax: +39.091.6552393; E-mail: gerardo.iacopino@unipa.it

Received March 21, 2015; Accepted April 15, 2015; Published April 17, 2015

Citation: Maugeri R, Anderson DG, Graziano F, Gerardi RM, Visocchi M, et al. (2015) Familial Replicating Arachnoidal Cysts: Case Series and Review of Literature. J Neurol Disord 3: 228. doi: 10.4172/2329-6895.1000228

Copyright: () 2015 Maugeri R, et al. This is an open-access article distributed under the terms of the Creative Commons Attribution License, which permits unrestricted use, distribution, and reproduction in any medium, provided the original author and source are credited. 


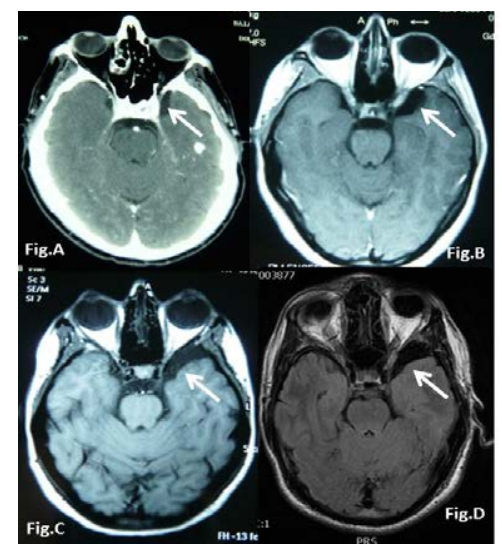

Axial brain $\mathrm{CT}$ image of the father (A) and axial brain MR images of his children; B-daughter 1, C- daughter 2 and $\mathrm{D}$ - son.

Figure 1: Axial brain CT image of the father $(A)$ and axial brain MR images of his children; B- daughter $1, \mathrm{C}$ - daughter 2 and $\mathrm{D}$ - son.

of girl's brother brain revealed an arachnoid cyst in the same region. The general physical findings of the four affected family members were normal. None had an increased head size or any abnormal cutaneous manifestations. The prenatal and perinatal histories for the affected subjects were unremarkable; all were born normally at term and none had any history of intrauterine exposure to infection, drugs, teratogens or trauma. Abdominal echography was performed to rule out polycystic kidney. Clinical picture lacked to reveal glutaric aciduria, nor muscular weakness make us suspect on the presence of oculopharingeal muscular dystrophy. Moreover the karyotype of the affected individuals was studied and found to be normal. Since the AC were consistent with Galassi Type 1, no surgical options were necessary but observation [7].

\section{Search strategy}

We performed a systematic review of the literature by using Medline and Scopus database. Studies were limited to those published in the English language. The following keywords were searched for by combining the term "arachnoid cyst" "familial" "genetic mutations". The search yielded a total of 81 articles. Of these, based on the titles and the abstracts, 32 articles were included after full-text review and bibliographic search, whose 15 referred to familial cases of arachnoid cyst.

\section{Discussion}

The incidence of arachnoid cysts, in the autopsy series, is 5 per 1000 [8]. In $10 \%$ of affected individuals, multiple cysts are found. Most AC $(>75 \%)$ are diagnosed in the pediatrics age group, mostly in the first six months of life. Arachnoid cysts may be asymptomatic throughout life and have also been shown to spontaneously regress in rare cases [1,9].

Although the precise causative mechanism is unknown, AC are now generally accepted to be developmental anomalies of arachnoid. These lesions have commonly been described in the literature, but the presence of familial arachnoid cysts is quite rare (Table 1).

Bright was the first to describe an intra arachnoidal cyst in 1831 [10]. In 1971 Robinson hypothesized that an AC of the middle cranial fossa originated from anomaly in mesenchymal differentiation, responsible of the agenesis of temporal lobe [11]. More recent studies have shown that compressed brain tissue surrounding the $\mathrm{AC}$ has the same weight as the contralateral "healthy" brain. Re-expansion of brain tissue following removal of an AC is also well known. These studies support the hypothesis that a middle cranial fossa AC is a developmental anomaly, occurring after the formation of the temporal lobe [12,13].

The first case described in literature of familial arachnoid cysts was of 1979 by Aarabi, et al. who reported a family in which father and the daughter harboring radicular pain, presented intradural arachnoid cysts at T8-9 and T5-6 respectively [4].

Other rare cases of spinal arachnoid intradural cysts, sometimes extradural, have been described, seldom associated with other conditions as the lymphedema-distichiasis syndrome [14,15]. Handa first described two brothers with bilateral arachnoid cysts of the middle cranial fossa. They presented in early childhood with head enlargement and were treated surgically; unfortunately one of them was mentally and physically retarded afterwards. Psychomotor delay is not a common clinical manifestation in cases of arachnoid cysts without a longstanding hydrocephalus. This symptom has been frequently recognized in cases of familial AC, suggesting a genetic common factor [16,17]. Bilateral arachnoid cysts in middle fossa have been often described in siblings with Glutaric Aciduria type 1 (GA-1), an autosomal recessively inherited metabolic disorder caused by a deficiency of glutaryl-coenzyme A dehydrogenase activity $[18,19]$.

Pomeranz, et al. reported a case of familial intracranial arachnoid cyst located on the convexity in three siblings: two male and one female. Three additional siblings in the family and other known relatives were clinically unaffected [20].

Tolmie, et al. in 1997 reported mother and son with mild mental handicap and arachnoid cyst in middle fossa, suggesting a mendelian inheritance [21].

Other reports describe familial case of arachnoid cysts in posterior fossa $[22,23]$.

Special cases lend support to the hypothesis that AC is caused by a genetic aetiology. For example, there is a strong association of $\mathrm{AC}$ with certain inheritable connective tissue disorders and syndromes such as Type 1 Neurofibromatosis, Autosomal dominant polycystic kidney disease, Type 1 Glutaric Aciduria, Occulopharyngeal muscular dystrophy, Marfan's syndrome and Autosomal dominant polycystic kidney disease (ADPKD) as reported in the literature [18,24].

Various chromosomal abnormalities have been found in patients affected by AC. Masuno, et al. described an association with partial distal 12q trisomy [25]. Souter et al. found a subtelomeric deletion of the distal long arm of chromosome 14, in a foetus with tetralogy of Fallot, intrauterine growth restriction, and a midline intracranial AC [26]. Hogge et al. reported partial trisomy $9 q$ and partial monosomyn $\mathrm{Xq}$ in a foetus with an infratentorial AC compressing the right cerebellar hemisphere [16]. Elbers and Furness reported the association of triploidy with a foetus with an arachnoid cyst [27].

Stein, et al. [25] reported prenatal diagnosis of trisomy 20 mosaicism associated with an arachnoid cyst of basal cistern [28,29]. Bilguvar, et al. described a syndrome of pachygyria, mental retardation, AC with a linkage to a single area at chromosome band 11p15 [30]. Degerliyurt et al. described a family with two siblings and mother affected by a mutation of Col4A1 who exhibited porencephaly, hemiparesis, epilepsy, atrophic kidney disease and AC [31]. In oculopharyngeal muscular dystrophy, a condition often associated with $\mathrm{AC}$, a possible linkage to PAPB2 gene and chromosome 14q11.2-q13 has been implicated [6].

Recently Arriola, et al. described two families with a familial pattern of AC and a deletion in 16q. One of the families also exhibited mental impairment. Both families manifested affected individuals in consecutive generations, suggesting an autosomal dominant pattern 


\begin{tabular}{|c|c|c|c|c|c|c|c|}
\hline Author & Year & $\begin{array}{l}\text { Family } \\
\text { members }\end{array}$ & Location & Mentality & $\begin{array}{l}\text { Associated } \\
\text { syndrome }\end{array}$ & $\begin{array}{l}\text { Genetic } \\
\text { anomalies }\end{array}$ & Chromosomial anomalies \\
\hline AArabi & 1979 & 2 & T6-T6 T8-T9 & $\begin{array}{l}\text { Normal } \\
\text { Normal }\end{array}$ & None & unknown & unknown \\
\hline Handa & 1981 & 2 & $\begin{array}{l}\text { Bilat. Middle cranial fossa } \\
\text { Bilat. Middle cranial fossa }\end{array}$ & Normal Delay & None & unknown & unknown \\
\hline Wilson & 1988 & 2 & $\begin{array}{l}\text { Left cerebral convex, Left } \\
\text { cerebral convex, }\end{array}$ & Delay Delay & None & unknown & unknown \\
\hline Pomeranz & 1991 & 3 & $\begin{array}{l}\text { Left cerebral convex, } \\
\text { Bilat. Cerebral convex, } \\
\text { ambient cystern }\end{array}$ & $\begin{array}{l}\text { Delay, Border, } \\
\text { Normal }\end{array}$ & None & unknown & unknown \\
\hline Martinez-Lage & 1994 & 2 & $\begin{array}{l}\text { Bilat. Middle cranial fossa } \\
\text { Bilat. Middle cranial fossa }\end{array}$ & Delay Delay & GA- $I^{\circ} \mathrm{GA}-I^{\circ}$ & unknown & unknown \\
\hline Jamjoom & 1995 & 2 & $\begin{array}{l}\text { Bilat. Middle cranial fossa } \\
\text { Bilat. Middle cranial fossa }\end{array}$ & Delay Delay & GA- $1^{\circ} \mathrm{GA}-1^{\circ}$ & unknown & unknown \\
\hline Tolmie & 1997 & 2 & $\begin{array}{l}\text { Middle cranial fossa } \\
\text { Middle cranial fossa }\end{array}$ & Delay Delay & None None & unknown & None None \\
\hline Jadeja & 2002 & 2 & $\begin{array}{l}\text { Left hemispheric Left } \\
\text { hemispheric }\end{array}$ & $\begin{array}{l}\text { Normal } \\
\text { Normal }\end{array}$ & OPMD* OPMD* & PAPB2 PAPB2 & Chromosome 14 Chromosome 14 \\
\hline Alehan & 2002 & 2 & $\begin{array}{l}\text { Posterior fossa Posterior } \\
\text { fossa }\end{array}$ & Delay Delay & ADPKD* ADPKD* & unknown & None \\
\hline Suzuki & 2002 & 2 & $\begin{array}{l}\text { Retrocerebellar } \\
\text { Retrocerebellar }\end{array}$ & Delay Delay & None None & unknown & unknown \\
\hline Sinha & 2004 & 2 & $\begin{array}{l}\text { Quadrigeminal cistern } \\
\text { Quadrigeminal cistern }\end{array}$ & $\begin{array}{l}\text { Unknown } \\
\text { Unknown }\end{array}$ & None & unknown & unknown \\
\hline \multirow{2}{*}{ Arriola } & \multirow{2}{*}{2005} & \multirow{2}{*}{$\begin{array}{l}\text { Family I } 3 \\
\text { Family II } 3\end{array}$} & $\begin{array}{l}\text { Posterior fossa Middle } \\
\text { cranial fossa Posterior } \\
\text { fossa }\end{array}$ & $\begin{array}{l}\text { Delay Delay } \\
\text { Delay }\end{array}$ & None & unknown & $\begin{array}{l}\text { Long arm chromosome } 16 \text { Long arm } \\
\text { chromosome } 16 \text { Long arm chromosome } \\
16\end{array}$ \\
\hline & & & $\begin{array}{l}\text { Paramesencephalic } \\
\text { Pineal Left parietal }\end{array}$ & $\begin{array}{l}\text { Normal } \\
\text { Normal } \\
\text { Normal }\end{array}$ & None & unknown & None None None \\
\hline Yabuki & 2007 & 7 & Spinal extradural & & $\mathrm{LSD}^{\wedge}$ & unknown & unknown \\
\hline $\begin{array}{l}\text { Sanchez- } \\
\text { Carpintero }\end{array}$ & 2010 & 7 & Spinal extradural & Normal & $\operatorname{LSD}^{\wedge}$ & FOXC2 & unknown \\
\hline Bayrakli & 2012 & 6 & Different localization & Normal & None & None & $\begin{array}{l}\text { Identified strong linkage with locus } \\
\text { chromosome 6q22.31-23.2 }\end{array}$ \\
\hline
\end{tabular}

Table 1: Series of familial cases of arachnoid cysts in literature.

of inheritance [5]. In contrast, Bayrakli, et al. described a family with intracranial AC that manifested a pattern consistent with autosomal recessive inheritance [32]. These data, taken together, suggest that more than one factor may be implicated in AC formation.

Our report describes a family with four members affected by arachnoid cysts in the same region and, more surprisingly, at the same site, up to our knowledge this is a unique description, already not reported in the literature. In these cases, the general physical findings including head size and cutaneous examination were normal. There was no history of intrauterine exposure to infection, drugs, teratogens or trauma. Genetic karyotyping was also normal.

This report extends previous observations and supports a possible, although unknown, genetic aetiology for some cases of primary AC with a possible mendelian inheritance of this kinship. Further studies are needed to confirm the origin of $\mathrm{AC}$ and demonstrate the mechanism of this important malformation of the nervous system.

\section{Conclusion}

Although a candidate gene leading to the formation of familial $\mathrm{AC}$ has not been identified, the current case report, along with the published literature, seems strongly to support that some cases of AC could have a genetic basis. Additional genetic studies of familial AC are mandatory to define the mechanism of $\mathrm{AC}$ formation.

\section{References}

1. Al-Holou WN, Yew AY, Boomsaad ZE, Garton HJ, Muraszko KM, et al. (2010) Prevalence and natural history of arachnoid cysts in children. Journal of Neurosurgery: Pediatrics 5: 578-585.

2. Handa J, Okamoto K, Sato M (1981) Arachnoid cyst of the middle cranial fossa: report of bilateral cysts in siblings. Surg Neurol 16:127-130.

3. Zaatreh MM, Bates ER, Hooper SR, Palmer G, Elmenshawi EE, et al. (2002) Morphometric and neuropsychologic studies in children with arachnoid cysts. Pediatr Neurol 26: 134-138.

4. Aarabi B, Pasternak G, Hurko O, Long DM (1979) Familial intradural arachnoid cysts. Report of two cases. J Neurosurg 50: 826-829.

5. Arriola G, de Castro P, Verdú A (2005) Familial arachnoid cysts. Pediatr Neurol 33: $146-148$.

6. Jadeja KJ, Grewal RP (2003) Familial arachnoid cysts associated with oculopharyngeal muscular dystrophy. J Clin Neurosci 10: 125-127.

7. Galassi E, Tognetti F, Gaist G, Fagioli L, Frank F (1982) CT scan and medtrizamide CT cisternography in arachnoid cysts of the middle cranial fossa: classification and pathophysiological aspects. Surg Neurol 17: 363-369.

8. Briellmann RS, Jackson GD, Tom-Broers, Berkovic SF (1998) Twins with different temporal malformations: schizencephaly and arachnoid cyst Neuropediatrics 29: 284-288.

9. Schmidek, Sweet (2012) Operative Neurosurgical Techniques: Indications, Methods and Results. (6thedn), Elsevier Saunders Edition, Philadelphia, USA.

10. Cohen A, Perneczky A (1998) Endoscopy and the management of third ventricular lesions. In: Apuzzo MLJ (ed) Surgery of the Third Ventricle. (2ndedn), Baltimore: Williams \& Wilkins, New york, USA. 
Citation: Maugeri R, Anderson DG, Graziano F, Gerardi RM, Visocchi M, et al. (2015) Familial Replicating Arachnoidal Cysts: Case Series and Review of Literature. J Neurol Disord 3: 228. doi: 10.4172/2329-6895.1000228

11. Robinson RG (1971) Congenital cysts of the brain: arachnoid malformation. Prog Neurol Surg 4: 133-174.

12. García Santos JM, Martínez-Lage J, Gilabert Ubeda A, Capel Alemán A, Climent Oltrá V (1993) Arachnoid cysts of the middle cranial fossa: a consideration of their origins based on imaging. Neuroradiology 35: 355-358.

13. Gosalakkal JA (2002) Intracranial arachnoid cysts in children: a review of pathogenesis, clinical features and management. Pediatric Neurology 26: 93-98.

14. Sánchez-Carpintero $R$, Dominguez $P$, Núñez MT, Patiño-García A (2010) Spinal extradural arachnoid cysts in lymphedema-distichiasis syndrome. Genet Med 12: 532-535.

15. Yabuki S, Kikuchi S, Ikegawa S (2007) Spinal extradural arachnoid cysts associated with distichiasis and lymphedema. Am J Med Genet A 143: 884-887

16. Hogge WA, Schnatterly P, Ferguson JE II (1995) Early prenatal diagnosis of an infratentorial arachnoid cyst: association with an unbalanced translocation. Prenat Diagn 15: 186-188.

17. Wilson WG, Deponte KA, Mcllhenny J, Dreifuss FE (1988) Arachnoid cysts in a brother and sister. J Med Genet;25: 714-715.

18. Jamjoom ZA, Okamoto E, Jamjoom AH, Al-Hajery O, Abu-Melha A (1995) Bilateral arachnoid cysts of the sylvian region in female siblings with glutaric aciduria type I. Report of two cases. J Neurosurg 82: 1078-1081.

19. Martínez-Lage JF, Casas C, Fernández MA, Puche A, Rodriguez Costa T, et al. (1994) Macrocephaly, dystonia, and bilateral temporal arachnoid cysts: glutaric aciduria type 1. Childs Nerv Syst.10: 198-203.

20. Pomeranz S, Constantini S, Lubetzki-Korn I, Amir N (1991) Familial intracranial arachnoid cysts. Childs Nerv Syst 7: 100-102.

21. Tolmie JL, Day R, Fredericks B, Galea P, Moffett AW (1997) Dominantly inherited cerebral dysplasia: arachnoid cyst associated with mild mental handicap in a mother and her son. J Med Genet 34: 1018-1020.

22. Sinha S, Brown JI (2004) Familial posterior fossa arachnoid cyst. Childs Nerv Syst 20: 100-103.
23. Suzuki H, Takanashi J, Sugita K, Barkovich AJ, Kohno Y (2002) Retrocerebellar arachnoid cysts in siblings with mental retardation and undescended testis. Brain Dev 24: 310-313.

24. Alehan FK, Gürakan B, Ağildere M (2002) Familial arachnoid cysts in association with autosomal dominant polycystic kidney disease. Pediatrics 110: 13.

25. Masuno M, Fukushima Y, Sugio Y, Kuroki Y (1987) Partial distal 12q trisomy with arachnoid cyst. Jinrui Idengaku Zasshi 32: 39-43.

26. Souter VL, Glass IA, Chapman DB, Raff ML, Parisi MA, et al. (2003) Multiple fetal anomalies associated with subtle subtelomeric chromosomal rearrangements. Ultrasound Obstet Gynecol 21: 609-615.

27. Elbers SEL, Furness ME (1999) Resolution of presumed arachnoid cyst in utero. Ultrasound Obstet Gynecol 14: 353-355.

28. Stein QP, Boyle JG, Crotwell PL, Flanagan JD, Johnson KJ, et al. (2008) Prenatally diagnosed trisomy 20 mosaicism associated with arachnoid cyst of basal cistern. Prenat Diagn 28: 1169-1170.

29. Chen CP, Su YN, Weng SL, Tsai FJ, Chen CY, et al. (2012) Rapid aneuploidy diagnosis of trisomy 18 by array comparative genomic hybridization using uncultured amniocytes in a pregnancy with fetal arachnoid cyst detected in late second trimester. Taiwan J Obstet Gynecol. 51: 481-484.

30. Bilguvar K, Ozturk AK, Bayrakli F, Guzel A, DiLuna ML, et al. (2009) The syndrome of pachygyria, mental retardation, and arachnoid cysts maps to 11p15. Am J Med Genet A 149: 2569-2572.

31. Değerliyurt A, Ceylaner G, Koçak H, Bilginer Gürbüz B, Cihan BS, et al. (2012) A new family with autosomal dominant porencephaly with a novel Col4A1 mutation. Are arachnoid cysts related to Col4A1 mutations? Genet Couns 23 185-193.

32. Bayrakli F, Okten Al, Kartal U, Menekse G, Guzel A, et al. (2012) Intracranial arachnoid cyst family with autosomal recessive trait mapped to chromosome 6q22.31-23.2. Acta Neurochir (Wien) 154: 1287-1292. 